\title{
Enhanced Thermostability of a Fungal Alkaline Protease by Different Additives
}

\author{
Nilesh P. Nirmal ${ }^{1}$ and R. Seeta Laxman ${ }^{2}$ \\ ${ }^{1}$ Department of Biochemistry, Faculty of Pharmaceutical Sciences, Burapha University, 169 Bangsaen Road, Saensook, \\ Muang, Chonburi 20131, Thailand \\ ${ }^{2}$ Division of Biochemical Sciences, National Chemical Laboratory, Pune 411 008, India \\ Correspondence should be addressed to Nilesh P. Nirmal; nirmalnp21@yahoo.co.in
}

Received 24 February 2014; Revised 12 June 2014; Accepted 17 June 2014; Published 3 July 2014

Academic Editor: Qi-Zhuang Ye

Copyright (c) 2014 N. P. Nirmal and R. S. Laxman. This is an open access article distributed under the Creative Commons Attribution License, which permits unrestricted use, distribution, and reproduction in any medium, provided the original work is properly cited.

A fungal strain (Conidiobolus brefeldianus MTCC 5184) isolated from plant detritus secreted a high activity alkaline protease. Thermostability studies of the fungal alkaline protease (FAP) revealed that the protease is stable up to $50^{\circ} \mathrm{C}$ with $40 \%$ residual activity after one hour. Effect of various additives such as sugars, sugar alcohols, polyols, and salts, on the thermostability of FAP was evaluated. Among the additives tested, glycerol, mannitol, xylitol, sorbitol, and trehalose were found to be very effective in increasing the stability of FAP, which was found to be concentration dependent. Fivefold increase in residual activity of FAP was observed in the presence of trehalose $(50 \%)$ and sorbitol $(50 \%)$ at $50^{\circ} \mathrm{C}$ for $4 \mathrm{~h}$, compared to FAP without additive. Other additives like calcium at $20 \mathrm{mM}$ and $10-15 \%$ ammonium sulphate showed lower stability improvement than trehalose and sorbitol. $\mathrm{NaCl}$, $\mathrm{MgCl}_{2}, \mathrm{~K}_{2} \mathrm{HPO}_{4}$, and glycine were found to be poor stabilizers and showed only a marginal improvement. PEG 6000 did not show any increase in stability but was found to be slightly inhibitory.

\section{Introduction}

Proteases are one of the largest groups of hydrolytic enzymes having $60 \%$ share in world enzyme market. Among them, alkaline proteases have been maximally exploited in food, leather, silk, detergent industries, and waste management. They are also used as important tools in studying the structure of certain oligopeptides, proteins, and polypeptides [1]. However, their overall potential in industrial processes is yet to be fully exploited. The use of enzymes for industrial purpose usually depends on their stability during isolation, purification, storage, and tough operational conditions. Higher thermostability is one of the crucial requirements of an enzyme for its application in industrial processes as it increases the efficiency of enzyme. Therefore, search for thermostable enzymes or enhancing thermostability of enzymes has been the priority of the industries or researchers.

Stabilization of enzymes in soluble form is very important as it is impossible to use insoluble enzymes in several biotechnological applications including detergent, food, cosmetic, and textile industries. Several approaches were carried out to improve stabilization of enzymes in soluble form, including changing the environment by means of additives such as sugars and osmolytes [2], alteration of primary structure of the enzyme by chemical modification [3], protein engineering [4], and introduction of disulphide bridge and covalent immobilization [5], through the formation of a reversible enzyme-inhibitor complex [6]. Addition of stabilizing agents is the simplest and cheapest method to achieve enhanced thermostability of enzymes. Various types of additives have been reported in the literature such as polyols, sugars, metals, surfactants, and salts. New additives are screened every day, which reflect the effectiveness of this method. However, some of these additives may interfere with the final use of the enzyme due to incompatibility with reaction system, mostly in pharmaceutical sector. Despite this, soluble additives were widely practiced in textile, leather, detergent industries, and waste management as a reliable stabilization method. For this study, only those compounds with a well-documented stabilizer for protease were considered. Stabilization by using 
such additives follows two paths: one by additive-solvent (water) interactions and another by additive-protein interaction. In most of the cases, additive-water interaction favors the thermostability of protein following preferential hydration principle where enzymes get stabilized. On the other hand, in additive-protein interaction most of the proteins are destabilized.

A large proportion of commercially available proteases are derived from Bacillus strains [7]. Fungal sources are being increasingly used $[8,9]$. Although bacterial proteases have been used in industrial processes long before, the high cost to obtain microbe-free enzyme limited its further promotion. Proteases from fungal origin offer an advantage where the mycelium can be easily removed by filtration. The optimization of fermentation parameters as well as scale up of production of this fungal alkaline protease has been reported earlier [8]. This protease has the potential for application in leather, silk degumming, and detergent industries. The present paper describes the temperature stability of a fungal alkaline protease and its improvement by different additives.

\section{Materials and Methods}

2.1. Chemicals. Malt extract, yeast extract, and peptone were obtained from Hi-Media Chemicals, India. Hammerstein casein was obtained from M/s Sisco Research Laboratories, India. Xylitol and trehalose were obtained from Sigma Chemical Co., USA. All other chemicals were of analytical grade.

2.2. Microorganism and Enzyme Production. The fungal strain (Conidiobolus brefeldianus MTCC 5184) used in the present study was isolated from plant detritus and maintained on MGYP (0.3\% malt extract; $1.0 \%$ glucose; $0.3 \%$ yeast extract; $0.5 \%$ peptone) agar slants. Protease was produced in $400 \mathrm{~L}$ fermentor in a simple medium containing glucose $(2.0 \%)$, yeast extract $(0.3 \%)$, and soybean meal $(3.0 \%)$ as described by Khandelwal [8]. Inoculum and seed for protease production were developed in $1 \mathrm{~L}$ conical flask and $35 \mathrm{~L}$ fermentor, respectively. Inoculum was developed by inoculating spores from 2- to-3-day-old MGYP slants in $200 \mathrm{~mL}$ GYEP medium (1\% glucose, $0.3 \%$ yeast extract, and $0.5 \%$ peptone). After incubation at $28^{\circ} \mathrm{C}$ and $180 \mathrm{rpm}$ for $12-16 \mathrm{~h}$, vegetative growth $(10 \% \mathrm{v} / \mathrm{v})$ was transferred to $35 \mathrm{~L}$ seed fermentor containing $25 \mathrm{~L}$ GYE (1\% glucose and $0.3 \%$ yeast extract) medium. Ten percent $(\mathrm{v} / \mathrm{v})$ of the vegetative growth was used to inoculate the $400 \mathrm{~L}$ fermentor containing $300 \mathrm{~L}$ medium. Aeration was maintained between 0.8 and $1 \mathrm{vvm}$. Agitation was kept initially at $70 \mathrm{rpm}$ and slowly increased to reach $80 \mathrm{rpm}$ at $45 \mathrm{~h}$ and was kept constant till the end of fermentation (48-55 h). Dissolved oxygen and temperature were maintained at $60-80 \%$ and $26-28^{\circ} \mathrm{C}$, respectively. Fermentor was terminated when activity started declining and mycelial biomass was separated from the broth by centrifugation in bucket centrifuges. The cell-free supernatant was concentrated by membrane filtration with $10 \mathrm{kDa}$ cut-off (PM-10 membrane) and used for stability studies.
2.3. Stability Studies. Effect of additives on thermal stability was determined by incubating the enzyme (1000 unit) preparation in the presence of additives at the desired concentrations and temperatures for a stipulated period of time. Sugars, sugar alcohols, metal ions, salts, and polyethylene glycol were used as additives. Aliquots were withdrawn at regular time intervals and cooled on ice for $15 \mathrm{~min}$ and residual activity was estimated at optimum condition $50^{\circ} \mathrm{C}, \mathrm{pH} 9$ [8]. The activity of enzyme without additive was considered as control and taken as $100 \%$.

2.4. Enzyme Assay. Protease activity was determined at $50^{\circ} \mathrm{C}$ and $\mathrm{pH} 9$ with $1 \%$ casein as substrate as described earlier [10] with slight modification. Briefly, the reaction mixture contained $1 \mathrm{~mL}$ of suitably diluted enzyme and $1 \mathrm{~mL}$ of $1 \%$ Hammerstein casein in $0.1 \mathrm{M}$ carbonate-bicarbonate buffer $\mathrm{pH}$ 9.0. After incubation at $50^{\circ} \mathrm{C}$ for $10 \mathrm{~min}$, the reaction was terminated by the addition of $3 \mathrm{~mL}$ of $5 \%$ trichloroacetic acid. The precipitate formed was filtered through Whatman number 1 filter paper after standing at room temperature for $30 \mathrm{~min}$. The absorbance of trichloroacetic acid soluble fraction was measured at $280 \mathrm{~nm}$. Amount of tyrosine produced is calculated from a precalibrated graph of absorbance at $280 \mathrm{~nm}$ against tyrosine concentration. One unit of protease activity was defined as the amount of enzyme liberating $1 \mu \mathrm{g}$ $\mathrm{Tyr} / \mathrm{mL} / \mathrm{min}$ under assay conditions.

2.5. Statistical Analysis. The experiments were run in triplicate. Data were presented as mean values with standard deviations. One way analysis of variance (ANOVA) was carried out and mean comparisons were run using Duncan's multiple range tests.

\section{Results and Discussion}

3.1. Thermostability of Protease. Thermostability of protease was evaluated by incubating the crude enzyme (1000 units) at temperatures ranging from 30 to $80^{\circ} \mathrm{C}$ for $1 \mathrm{~h}$ (Figure 1). The enzyme was stable up to $40^{\circ} \mathrm{C}$ and around $50 \%$ activity was retained at $50^{\circ} \mathrm{C}$ while complete loss was observed above this temperature. These results are consistent with thermal stabilities of other fungal proteases reported in literature. Penicillium protease was not stable above $35^{\circ} \mathrm{C}$ and residual activities after $1 \mathrm{~h}$ at 35,45 , and $50^{\circ} \mathrm{C}$ were 90,60, and $20 \%$, respectively [11]. Aspergillus parasiticus protease was stable up to $40^{\circ} \mathrm{C}$ for $1 \mathrm{~h}$ incubation but was inactivated above this temperature [12]. This is comparable to the present fungal protease which retained around $90 \%$ of activity at $40^{\circ} \mathrm{C}$ after $1 \mathrm{~h}$. The present fungal protease retained more than $65 \%$ activity at $28^{\circ} \mathrm{C}$ during $24 \mathrm{~h}$ of incubation (data not shown). These results are consistent with alkaline protease from Conidiobolus coronatus which was stable at $28^{\circ} \mathrm{C}$ for $20 \mathrm{~h}$ and at $40^{\circ} \mathrm{C}$ for $1 \mathrm{~h} \mathrm{[13].}$

The alkaline proteinase from Fusarium culmorum was heat labile and residual activities after $50 \mathrm{~min}$ at 24, 40, 50, and $60^{\circ} \mathrm{C}$ were $88,55,29$, and $0 \%$, respectively [14]. Our fungal protease was more thermostable at $50^{\circ} \mathrm{C}$ (half-life around $50 \mathrm{~min}$ ) than the proteases from A. clavatus ES1 (half-life: 
TABLE 1: Effect of $\mathrm{CaCl}_{2}$ and $\mathrm{MgCl}_{2}$ on thermostability of fungal alkaline protease during $3 \mathrm{~h}$ of incubation at $50^{\circ} \mathrm{C}$.

\begin{tabular}{|c|c|c|c|c|c|c|c|}
\hline \multirow{3}{*}{ Time (min) } & \multicolumn{7}{|c|}{ Residual activity (\%) } \\
\hline & \multirow{2}{*}{ Control } & \multicolumn{3}{|c|}{$\mathrm{CaCl}_{2}(\mathrm{mM})$} & \multicolumn{3}{|c|}{$\mathrm{MgCl}_{2}(\mathrm{mM})$} \\
\hline & & 5 & 10 & 20 & 5 & 10 & 20 \\
\hline 0 & 100 & 100 & 100 & 100 & 100 & 100 & 100 \\
\hline 30 & $73.4 \pm 0.91^{\mathrm{d}}$ & $81.5 \pm 1.92^{\mathrm{c}}$ & $91.7 \pm 1.3^{\mathrm{b}}$ & $96.9 \pm 1.64^{\mathrm{a}}$ & $72.7 \pm 0.21^{\mathrm{d}}$ & $91.9 \pm 0.89^{\mathrm{b}}$ & $91.8 \pm 0.64^{\mathrm{b}}$ \\
\hline 60 & $44.4 \pm 0.48^{\mathrm{f}}$ & $61.1 \pm 0.65^{\mathrm{d}}$ & $73.2 \pm 0.35^{\mathrm{b}}$ & $79.8 \pm 1.34^{\mathrm{a}}$ & $54.7 \pm 0.72^{\mathrm{e}}$ & $64.3 \pm 1.16^{\mathrm{d}}$ & $70.3 \pm 1.37^{\mathrm{c}}$ \\
\hline 120 & $22.7 \pm 0.19^{g}$ & $44.0 \pm 0.44^{\mathrm{e}}$ & $63.8 \pm 1.00^{\mathrm{b}}$ & $68.1 \pm 1.13^{\mathrm{a}}$ & $39.0 \pm 0.49^{\mathrm{f}}$ & $47.2 \pm 0.48^{\mathrm{d}}$ & $58.8 \pm 0.31^{\mathrm{c}}$ \\
\hline 180 & $17.4 \pm 0.38^{\mathrm{g}}$ & $34.8 \pm 0.42^{\mathrm{d}}$ & $54.6 \pm 2.44^{\mathrm{b}}$ & $56.9 \pm 0.89^{\mathrm{a}}$ & $28.3 \pm 0.40^{\mathrm{f}}$ & $32.2 \pm 0.46^{\mathrm{e}}$ & $41.7 \pm 0.41^{\mathrm{c}}$ \\
\hline
\end{tabular}

Values represent mean \pm SD from triplicates. Different small letters in the same row indicate significant difference $(P<0.05)$.

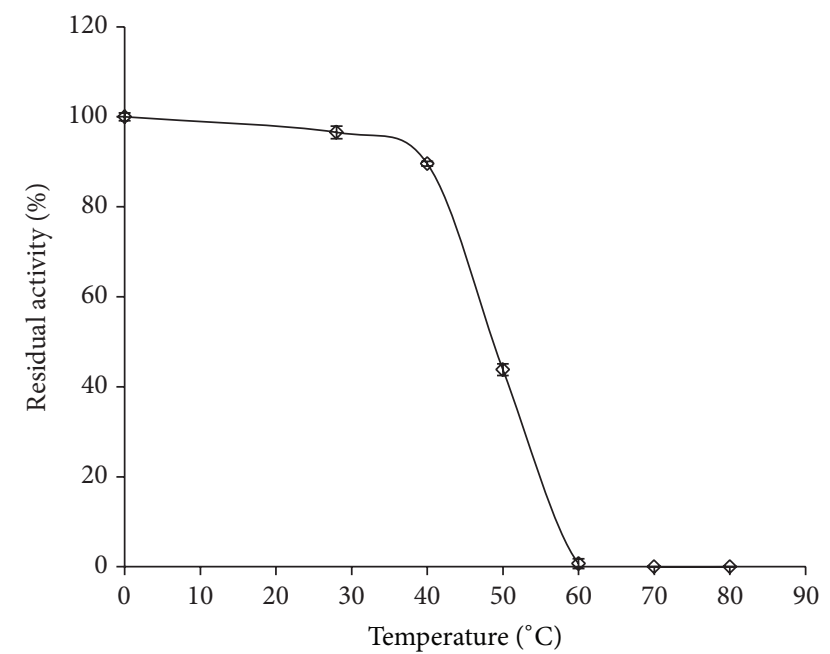

Figure 1: Thermostability of fungal alkaline protease during $1 \mathrm{~h}$ incubation at different temperatures. Values are mean \pm standard deviation $(n=3)$

$30 \mathrm{~min}$ ) and A. clavatus CCT2759 (half-life: $18 \mathrm{~min}$ ) $[15,16]$. The present fungal protease was less stable than Aspergillus fumigatus TKU003 protease which retained its initial activity from 25 to $50^{\circ} \mathrm{C}$ and $47 \%$ of its activity at $60^{\circ} \mathrm{C}$ but was completely inactivated at $70^{\circ} \mathrm{C}$ after $30 \mathrm{~min}$ [17]. However, FAP was optimally active at $50^{\circ} \mathrm{C}[8]$. Hence, all further stability studies were carried out at $50^{\circ} \mathrm{C}$.

3.2. Effect of $\mathrm{CaCl}_{2}$ and $\mathrm{MgCl}_{2}$. $\mathrm{Ca}^{2+}$ is a known activator of protease activity and also offers protection against thermal inactivation. Effect of $\mathrm{Ca}^{2+}$ and $\mathrm{Mg}^{2+}$ on stability of fungal alkaline protease was studied by incubating the enzyme with varying concentrations of $\mathrm{CaCl}_{2}$ and $\mathrm{MgCl}_{2}$ (5 to $20 \mathrm{mM}$ ) at $50^{\circ} \mathrm{C}$ up to $3 \mathrm{~h}$ (Table 1 ). In general, residual activity of FAP decreased as the incubation time increased $(P<0.05)$. However, decrease in residual activity was lowered in FAP with additives as compared to control $(P<0.05)$. $\mathrm{Ca}^{2+}$ was found to be a better protectant compared to $\mathrm{Mg}^{2+}$ at all the concentrations tested. Increasing the metal ion concentration increased the thermostability of FAP at $50^{\circ} \mathrm{C} .20 \mathrm{mM} \mathrm{Ca}^{2+}$ increased the stability by $2-3$ times compared to control especially after $60 \mathrm{~min}$. Residual activities at the end of $3 \mathrm{~h}$ of incubation at $50^{\circ} \mathrm{C}$ in control, in presence of $20 \mathrm{mM} \mathrm{Ca}^{2+}$ and $20 \mathrm{mM} \mathrm{Mg}^{2+}$, were $17.4 \%, 56.9 \%$, and $41.7 \%$, respectively. The protective effect of $5 \mathrm{mM} \mathrm{Ca}^{2+}$ was similar to that with $10 \mathrm{mM}$ $\mathrm{Mg}^{2+}$, but effect of $20 \mathrm{mM} \mathrm{Mg}^{2+}$ was less than $10 \mathrm{mM} \mathrm{Ca}^{2+}$. Similar pattern of increase in thermostability by $\mathrm{Ca}^{2+}$ was also observed in alkaline proteases from P. lilacinus, Aspergillus oryxae, A. tamarii, and Conidiobolus coronatus [13, 18-20]. $5 \mathrm{mM} \mathrm{CaCl}{ }_{2}$ offered maximum protection against thermal inactivation of $A$. tamarii protease increasing the half-life at $55^{\circ} \mathrm{C}$ from 20 to $140 \mathrm{~min}$. But the protective effect gradually decreased with increasing $\mathrm{CaCl}_{2}$ concentration, while the addition of other salts such as $\mathrm{MgCl}_{2}, \mathrm{MnCl}_{2}$, and $\mathrm{NaCl}$ did not offer any protection [20]. Addition of $1 \mathrm{mM} \mathrm{Ca}^{2+}$ increased the stability of $P$. lilacinus proteinase at $60^{\circ} \mathrm{C}$ by 2.5 times [18]. $\mathrm{Ca}^{2+}$ ion played a vital role in maintaining the active confirmation of the enzyme at higher temperatures [21]. The protective effect of $\mathrm{Ca}^{2+}$ against thermal inactivation is speculated to be due to the strengthening of intramolecular interactions in the protein molecule as well as the binding of $\mathrm{Ca}^{2+}$ to autolysis sites.

3.3. Effect of Glycine. Effect of 0.5 and $1 \mathrm{M}$ glycine was investigated on thermostability of FAP. Glycine at both concentrations $(0.5$ and $1 \mathrm{M})$ increased the stability of the enzyme by almost 1.7-2.2 times over control, especially after $1 \mathrm{~h}$ of incubation (Table 2). There was no additional benefit in increasing the concentration of glycine beyond $0.5 \mathrm{M}$ as the residual activities for 0.5 and $1 \mathrm{M}$ glycine after $3 \mathrm{~h}$ were 31.6 and 35.2 , respectively, as compared to $16.11 \%$ in control. Addition of $1 \mathrm{M}$ glycine was found to be effective in improving the stability of C. coronatus protease which retained $31 \%$ of activity after incubation at $50^{\circ} \mathrm{C}$ for $1 \mathrm{~h}$ as compared to control and the half-life of the enzyme increased from 17 to $42 \mathrm{~min}$ [13]. Anjum et al. [22] studied the compatibility of osmolytes (glycine, proline, and sarcosine) with the Gibbs energy of stabilization of proteins (on heat induced denaturation of lysozyme, ribonuclease A, cytochrome $\mathrm{c}$, and myoglobin). They observed an increase in $T_{m}$ (midpoint of the denaturation) with an increase in osmolyte concentration without change in Gibbs energy of stabilization. The main factor responsible for the stabilizing effect was correlated with the preferential exclusion of the osmolytes from the protein 
TABLE 2: Effect of glycine on thermostability of fungal alkaline protease during $3 \mathrm{~h}$ of incubation at $50^{\circ} \mathrm{C}$.

\begin{tabular}{lccr}
\hline Time (min) & & Residual activity (\%) & Glycine (M) \\
\hline 0 & Control & 0.5 & 1 \\
60 & 100 & 100 & 560 \\
120 & $43.8 \pm 0.72^{\mathrm{c}}$ & $54.2 \pm 0.60^{\mathrm{b}}$ & $40.1 \pm 0.41^{\mathrm{a}}$ \\
180 & $23.3 \pm 0.38^{\mathrm{c}}$ & $39.9 \pm 0.53^{\mathrm{a}}$ & $35.2 \pm 0.12^{\mathrm{a}}$ \\
\hline
\end{tabular}

Values represent mean \pm SD from triplicates. Different small letters in the same row indicate significant difference $(P<0.05)$.

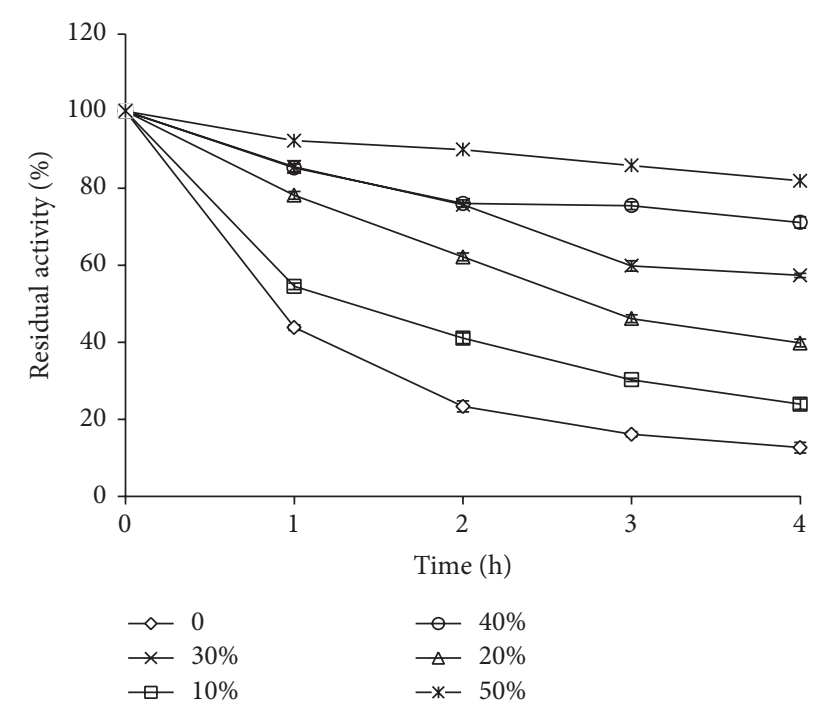

FIGURE 2: Effect of trehalose on thermostability of fungal alkaline protease during $4 \mathrm{~h}$ incubation at $50^{\circ} \mathrm{C}$. Values are mean \pm standard deviation $(n=3)$.

domain leading to the protein with lower exposed surface, thereby displacing the denaturation equilibrium towards native state. Thus, osmolytes are known to be effective in increasing thermostability and function by promoting the refolding and reactivation of the thermally unfolded proteins.

3.4. Effect of Trehalose. Effect of trehalose ( $\alpha$-D-glucopyranosyl- $\alpha$-D-glucopyranoside), a nonreducing sugar on thermostability of FAP, was investigated in the concentration range of 10 to $50 \%$. Extent of stability of the protease was dependent on trehalose concentration and nearly 2-6-fold increase was observed in comparison with control (Figure 2). More than $80 \%$ activity was retained even after $4 \mathrm{~h}$ at $50^{\circ} \mathrm{C}$ in presence of $50 \%$ trehalose compared to $12 \%$ in controls under identical conditions. At the concentration of $30 \%$ trehalose, more than $50 \%$ of FAP activity was observed. Trehalose is reported to effectively prevent protein denaturation and aggregation of denatured proteins at high temperatures. It is known to increase the thermostability of an enzyme by changing its microenvironment [23].

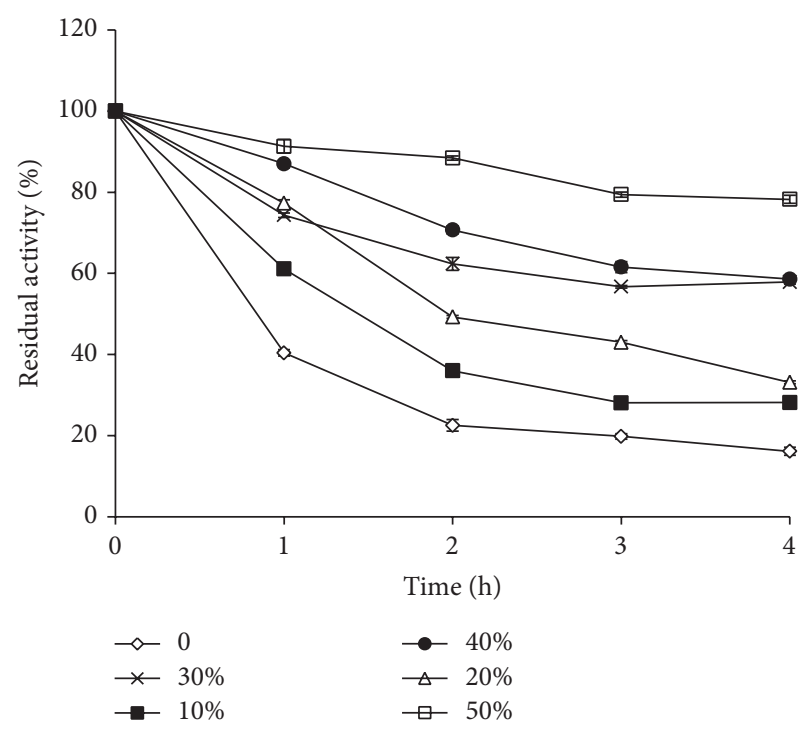

FIGURE 3: Effect of sorbitol on thermostability of fungal alkaline protease during $4 \mathrm{~h}$ incubation at $50^{\circ} \mathrm{C}$. Values are mean \pm standard deviation $(n=3)$.

Therefore, trehalose plays an important role in preventing protein denaturation at high temperature by changing its microenvironment and suppressing the aggregation of denatured proteins.

3.5. Effect of Polyols. Stability of FAP in presence of sugar alcohols including glycerol, mannitol, sorbitol, and xylitol was investigated. All sugar alcohols increased the stability by several folds over control, with the effect being more pronounced where enzyme was incubated for longer times (Table 3). At 10\% concentration, the half-life of the enzyme increased from $50 \mathrm{~min}$ in control in the absence of additive to $80,60,90$, and $75 \mathrm{~min}$ for glycerol, mannitol, sorbitol, and xylitol, respectively. At $20 \%$ concentration, the half-life of the enzyme further increased from $50 \mathrm{~min}$ in control to $90,115,135$, and $95 \mathrm{~min}$ for glycerol, mannitol, sorbitol, and xylitol, respectively. Since sugar alcohols were found to be very effective, all the sugar alcohols were also evaluated at 50\% which increased the half-lives from $50 \mathrm{~min}$ in control to more than $240 \mathrm{~min}$, the longest duration tested (data not shown). It is worth mentioning that $50 \%$ sorbitol 


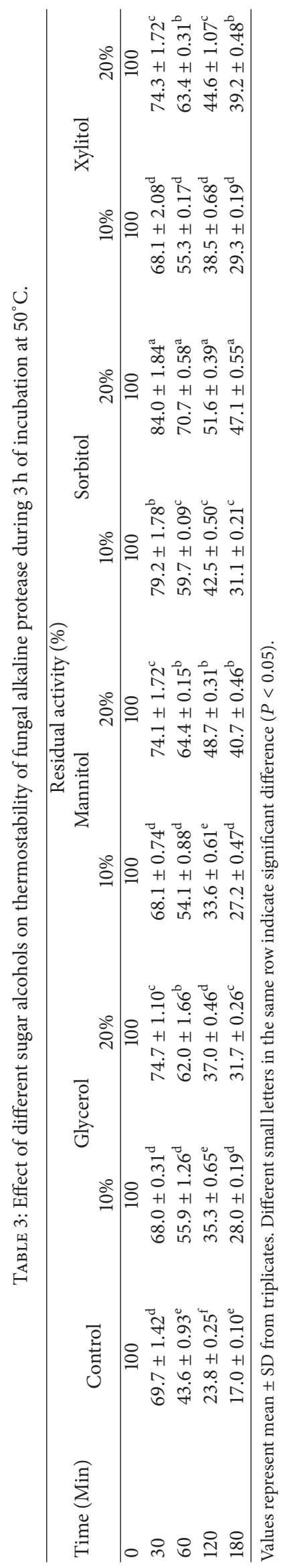


TABLE 4: Effect of PEG 6000 onthermostability of fungal alkaline protease during $3 \mathrm{~h}$ of incubation at $50^{\circ} \mathrm{C}$.

\begin{tabular}{lcccc}
\hline \multirow{2}{*}{ Time (min) } & & \multicolumn{3}{c}{ Residual activity (\%) } \\
& Control & 5 & PEG (\%) & 10 \\
\hline 0 & 100 & 100 & 100 & 100 \\
30 & $68.0 \pm 1.17^{\mathrm{a}}$ & $52.4 \pm 0.75^{\mathrm{b}}$ & $53.6 \pm 2.15^{\mathrm{b}}$ & $38.9 \pm 1.02^{\mathrm{c}}$ \\
60 & $43.2 \pm 0.20^{\mathrm{a}}$ & $37.9 \pm 1.03^{\mathrm{b}}$ & $32.9 \pm 0.29^{\mathrm{c}}$ & $19.1 \pm 0.16^{\mathrm{d}}$ \\
120 & $22.5 \pm 0.05^{\mathrm{a}}$ & $21.2 \pm 0.50^{\mathrm{a}}$ & $18.6 \pm 0.29^{\mathrm{b}}$ & $11.6 \pm 0.18^{\mathrm{c}}$ \\
180 & $16.7 \pm 0.12^{\mathrm{a}}$ & $12.4 \pm 0.05^{\mathrm{b}}$ & $10.9 \pm 0.30^{\mathrm{c}}$ & $8.5 \pm 0.14^{\mathrm{d}}$ \\
\hline
\end{tabular}

Values represent mean \pm SD from triplicates. Different small letters in the same row indicate significant difference $(P<0.05)$.

TABLE 5: Effect of $\mathrm{NaCl}$ and $\mathrm{K}_{2} \mathrm{HPO}_{4}$ on thermostability of fungal alkaline protease during $3 \mathrm{~h}$ of incubation at $50^{\circ} \mathrm{C}$.

\begin{tabular}{lccccc}
\hline & & \multicolumn{4}{c}{ Residual activity (\%) } \\
Time (min) & Control & \multicolumn{2}{c}{$\mathrm{NaCl}(\mathrm{M})$} & 1 & $\mathrm{~K}_{2} \mathrm{HPO}_{4}(\mathrm{M})$ \\
\hline 0 & 100 & 100 & 100 & 10.5 & 100 \\
30 & $70.4 \pm 0.91^{\mathrm{c}}$ & $77.8 \pm 0.71^{\mathrm{b}}$ & $80.5 \pm 0.57^{\mathrm{a}}$ & $70.1 \pm 1.85^{\mathrm{c}}$ & $71.3 \pm 0.80^{\mathrm{c}}$ \\
60 & $44.4 \pm 0.48^{\mathrm{d}}$ & $54.1 \pm 1.16^{\mathrm{b}}$ & $62.0 \pm 0.53^{\mathrm{a}}$ & $50.0 \pm 0.71^{\mathrm{c}}$ & $57.5 \pm 0.94^{\mathrm{b}}$ \\
120 & $21.8 \pm 0.58^{\mathrm{d}}$ & $48.8 \pm 0.57^{\mathrm{a}}$ & $49.2 \pm 0.25^{\mathrm{a}}$ & $36.7 \pm 0.13^{\mathrm{c}}$ & $47.1 \pm 0.31^{\mathrm{b}}$ \\
180 & $17.4 \pm 0.38^{\mathrm{d}}$ & $37.4 \pm 0.30^{\mathrm{a}}$ & $37.6 \pm 0.62^{\mathrm{a}}$ & $24.9 \pm 0.22^{\mathrm{c}}$ & $28.7 \pm 0.14^{\mathrm{b}}$ \\
\hline
\end{tabular}

Values represent mean \pm SD from triplicates. Different small letters in the same row indicate significant difference $(P<0.05)$.

increased the stability by 4-5 times as compared to control when incubated beyond $1 \mathrm{~h}$ with $80 \%$ original activity being retained even after $4 \mathrm{~h}$ while it was $16 \%$ in control under identical conditions (Figure 3). The residual activities after $1 \mathrm{~h}$ at $60^{\circ} \mathrm{C}$ in absence and presence of $50 \%$ sorbitol were $<1 \%$ and $52.9 \%$, respectively. Though $50 \%$ sorbitol increased the stability of protease at $60^{\circ} \mathrm{C}$, it could not offer protection above this temperature and complete loss in activity was noticed within $1 \mathrm{~h}$ even in presence of $50 \%$ sorbitol (data not shown). Water plays an important role in influencing the thermostability of enzymes. A range of low-molecular weight additives, such as sugars and polyols, exert stabilizing effect by inducing preferential hydration of proteins. At least in case of polyols, the preferential hydration arises from an increase in the surface tension of solvent water [24]. Loss of the protein's compact, properly folded structure increases the protein solvent interface which in turn tends to increase the degree of thermodynamically unfavourable interaction between the additive and the protein molecule resulting in the stabilization of protein by the additive [22]. 1\% glycerol and $800 \mathrm{mM}$ sorbitol offered limited protection against thermal inactivation of C. coronatus protease at $50^{\circ} \mathrm{C}[13]$.

Addition ofglycerol, sucrose, mannitol, sorbitol, and starchincreased the half-life of an alkaline protease from $B$ mojavensis at $60^{\circ} \mathrm{C}$ by 2-2.2-fold [25]. Addition of $3 \mathrm{M}$ sorbitol also improved the thermal stability of B. cereus BG1 alkaline protease at $60^{\circ} \mathrm{C}$ by 2 -fold [26]. The protective effects were explained by the strengthening of the hydrophobic interactions inside protein molecules and by indirect action of polyols on water structure.

3.6. Effect of PEG 6000. PEG 6000 in concentration range of $5-15 \%$ had no beneficial effect on stability of protease. In fact, there was slight decrease in the residual activity at all the concentrations and at all the incubation times tested (Table 4). 10\% PEG 8000 offered limited protection against thermal inactivation of C. coronatus protease at $50^{\circ} \mathrm{C}$ [13]. Actual mechanism of stabilization by polyethylene glycols (PEGs) is not yet well understood. It has been suggested that ethylene glycol is likely to stabilize polar proteins, while destabilizing nonpolar ones [23]. The effectiveness of PEG on proteins highly depends on the polymer molecular weight and on the protein structure. PEGs with high molecular weights are believed to prevent protein-protein interactions, leading to stabilization. In the present investigation, PEG 6000 showed slight inactivation/denaturation, and inactivation increased with an increase in PEG added. It suggested that increased hydrocarbon chain affects the protease structure which interferes with its refolding.

3.7. Effect of $\mathrm{NaCl}$ and $\mathrm{K}_{2} \mathrm{HPO}_{4}$. Inorganic salts have been investigated for their influence on the stability of enzymes $[13,20]$. Effect of $\mathrm{NaCl}(0.5$ and $1 \mathrm{M}), \mathrm{K}_{2} \mathrm{HPO}_{4}(0.5$ and $1 \mathrm{M})$, and $\left(\mathrm{NH}_{4}\right)_{2} \mathrm{SO}_{4}(5,10$, and $15 \%)$ on thermostability of protease at $50^{\circ} \mathrm{C}$ was investigated. Both 0.5 and $1 \mathrm{M} \mathrm{NaCl}$ increased stability of protease by 2 times. Residual activity after $3 \mathrm{~h}$ in case of control was around 17. 4\%, which increased to $37.4 \%$ in presence of $\mathrm{NaCl}$ (Table 5). There was no added advantage of $1 \mathrm{M} \mathrm{NaCl}$ as residual activities were more or less similar to $0.5 \mathrm{M} \mathrm{NaCl}$. Effect of $0.5 \mathrm{M} \mathrm{K}_{2} \mathrm{HPO}_{4}$ was not very significant but stabilizing effect of $1 \mathrm{M} \mathrm{K}_{2} \mathrm{HPO}_{4}$ was similar to that of $0.5 \mathrm{M} \mathrm{NaCl}$. 0.2 M NaCl had no beneficial effect on the stability of $C$. coronatus protease [13].

Ammonium sulphate, a known stabilizer, was examined for its stabilizing effect in the concentration range of 5 to $15 \%$ (concentration at which no precipitation was observed). 


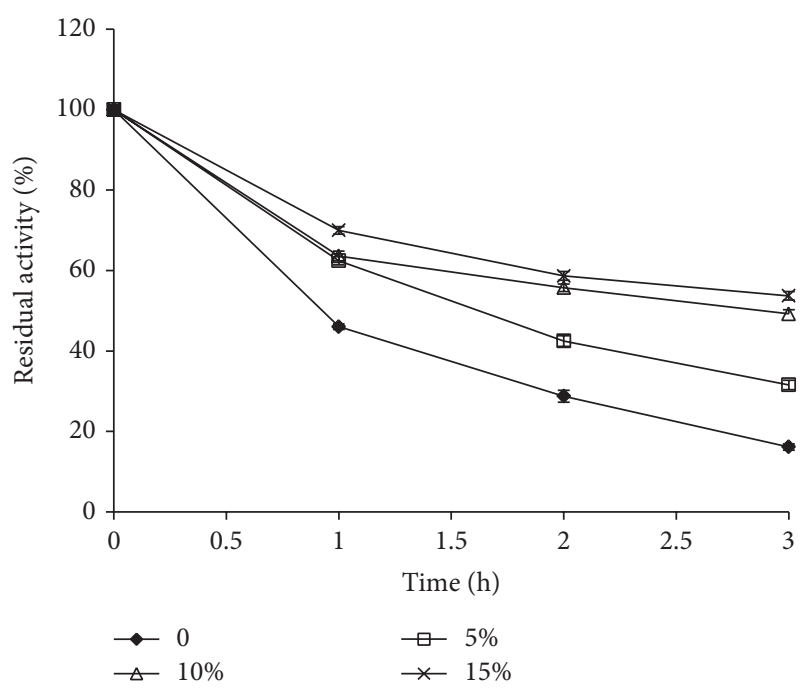

FIGURE 4: Effect of ammonium sulphate on thermostability of fungal alkaline protease during $3 \mathrm{~h}$ incubation at $50^{\circ} \mathrm{C}$. Values are mean \pm standard deviation $(n=3)$.

Ammonium sulphate increased the stability which was found to be concentration dependent (Figure 4). 15\% ammonium sulphate increased the stability at $50^{\circ} \mathrm{C}$ by 3 -fold. Salts such as $\mathrm{MgCl}_{2}, \mathrm{MnCl}_{2}$, and $\mathrm{NaCl}$ were found to be ineffective in protecting $A$. tamarii protease against thermal inactivation [20]. Salts play an important role in thermostabilization by known mechanism of "salting in" at low concentration; here, it also obeys preferential principle of hydration and addition of $15 \%$ ammonium sulphate resulted in 3 -fold increase in stability as compared to control.

\section{Conclusions}

The fungal alkaline protease retained more than $60 \%$ activity after $24 \mathrm{~h}$ at $28^{\circ} \mathrm{C}$ and $1 \mathrm{~h}$ at $40^{\circ} \mathrm{C}$ and around $50 \%$ activity was retained at $50^{\circ} \mathrm{C}$, while a complete loss was observed above this temperature. $\mathrm{Ca}$ and $\mathrm{Mg}$, trehalose, sugar alcohols, and salts like $\mathrm{NaCl}$ and ammonium sulphate offered protection to varying degrees against thermal inactivation at $50^{\circ} \mathrm{C}$, while $\mathrm{Ca}$ was better than $\mathrm{Mg}$. Among the additives tested, trehalose and the sugar alcohols especially sorbitol were found to be the best stabilizers with $80 \%$ residual activity after $4 \mathrm{~h}$ incubation at $50^{\circ} \mathrm{C}$. Thermal stability increases the efficiency of enzymes and is one of the essential features for their commercial exploitation. The present fungal protease is more thermostable than proteases from Penicillium sp., Fusarium culmorum, A. clavatus, Beauveria bassiana, S. brevicaulis, and C. coronatus but less stable than protease from Aspergillus tamarii.

\section{Conflict of Interests}

The authors declare that there is no conflict of interests regarding the publication of this paper.

\section{Acknowledgments}

The authors thank the Council of Scientific and Industrial Research (CSIR, Government of India) for financial assistance. The work was carried out under NMITLI Project on Biotechnology of Leather towards cleaner processing.

\section{References}

[1] C. G. Kumar and H. Takagi, "Microbial alkaline proteases: from a bioindustrial viewpoint," Biotechnology Advances, vol. 17, no. 7, pp. 561-594, 1999.

[2] M. N. Gupta, "Thermostabilization of proteins," Biotechnology and Applied Biochemistry, vol. 14, pp. 1-11, 1991.

[3] C. Bieniarz, M. J. Cornwell, and D. F. Young, "Alkaline phosphatase activatable polymeric cross-linkers and their use in the stabilization of proteins," Bioconjugate Chemistry, vol. 9, no. 3, pp. 390-398, 1998.

[4] P. N. Bryan, "Protein engineering of subtilisin," Biochimica et Biophysica Acta, vol. 1543, no. 2, pp. 203-222, 2000.

[5] J. Parrado, F. Millan, and J. Bautista, "Kerase immobilization by covalent attachment to porous glass," Process Biochemistry, vol. 30, no. 8, pp. 735-741, 1995.

[6] J. Pandhare, K. Zog, and V. V. Deshpande, "Differential stabilities of alkaline protease inhibitors from actinomycetes: effect of various additives on thermostability," Bioresource Technology, vol. 84, no. 2, pp. 165-169, 2002.

[7] R. Gupta, Q. K. Beg, S. Khan, and B. Chahuan, "An overview on fermentation, down stream processing and properties of microbial alkaline proteases," Applied Microbiology and Biotechnology, vol. 60, pp. 381-395, 2002.

[8] H. Khandelwal, Production, purification and characterization of fungal alkaline protease and its applications, National Chemical Laboratory, Pune, India, 2013.

[9] S. U. Phadatare, V. V. Deshpande, and M. C. Srinivasan, "High activity alkaline protease from Conidiobolus coronatus (NCL 86.8.20): enzyme production and compatibility with commercial detergents," Enzyme and Microbial Technology, vol. 15, no. 1, pp. 72-76, 1993.

[10] R. S. Laxman, A. P. Sonawane, S. V. More et al., "Optimization and scale up of production of alkaline protease from Conidiobolus coronatus," Process Biochemistry, vol. 40, no. 9, pp. 3152-3158, 2005.

[11] S. Germano, A. Pandey, C. A. Osaku, S. N. Rocha, and C. R. Soccol, "Characterization and stability of proteases from Penicillium sp. produced by solid-state fermentation," Enzyme and Microbial Technology, vol. 32, no. 2, pp. 246-251, 2003.

[12] R. Tunga, B. Shrivastava, and R. Banerjee, "Purification and characterization of a protease from solid state cultures of Aspergillus parasiticus," Process Biochemistry, vol. 38, no. 11, pp. 1553-1558, 2003.

[13] S. H. Bhosale, M. B. Rao, V. V. Deshpande, and M. C. Srinivasan, "Thermostability of high-activity alkaline protease from Conidiobolus coronatus (NCL 86.8.20)," Enzyme and Microbial Technology, vol. 17, no. 2, pp. 136-139, 1995.

[14] A. I. Pekkarinen, B. L. Jones, and M. Niku-Paavola, "Purification and properties of an alkaline proteinase of Fusarium culmorum," European Journal of Biochemistry, vol. 269, no. 3, pp. 798-807, 2002.

[15] M. Hajji, S. Kanoun, M. Nasri, and N. Gharsallah, "Purification and characterization of an alkaline serine-protease produced by 
a new isolated Aspergillus clavatus ES1," Process Biochemistry, vol. 42, no. 5, pp. 791-797, 2007.

[16] C. R. Tremacoldi, R. Monti, H. S. Selistre-De-Araújo, and E. C. Carmona, "Purification and properties of an alkaline protease of Aspergillus clavatus," World Journal of Microbiology and Biotechnology, vol. 23, no. 2, pp. 295-299, 2007.

[17] S. Wang, Y. Chen, C. Wang, Y. Yen, and M. Chern, "Purification and characterization of a serine protease extracellularly produced by Aspergillus fumigatus in a shrimp and crab shell powder medium," Enzyme and Microbial Technology, vol. 36, no. 5-6, pp. 660-665, 2005.

[18] E. K. Kotlova, N. M. Ivanova, M. P. Yusupova, T. L. Voyushina, N. E. Ivanushkina, and G. G. Chestukhina, "Thiol-dependent serine proteinase from Paecilomyces lilacinus: purification and catalytic properties," Biochemistry, vol. 72, no. 1, pp. 117-123, 2007.

[19] K. Ikegaya, S. Sugio, K. Murakami, and K. Yamanouchi, "Kinetic analysis of enhanced thermal stability of an alkaline protease with engineered twin disulfide bridges and calcium-dependent stability," Biotechnology and Bioengineering, vol. 81, no. 2, pp. 187-192, 2003.

[20] C. G. Boer and R. M. Peralta, "Production of extracellular protease by Aspergillus tamarii," Journal of Basic Microbiology, vol. 40, no. 2, pp. 75-81, 2000.

[21] H. S. Joo, C. G. Kumar, G. C. Park, S. R. Paik, and C. S. Chang, "Oxidant and SDS-stable alkaline protease from Bacillus clausii I-52: production and some properties," Journal of Applied Microbiology, vol. 95, no. 2, pp. 267-272, 2003.

[22] F. Anjum, V. Rishi, and F. Ahmad, "Compatibility of osmolytes with Gibbs energy of stabilization of proteins," Biochimica et Biophysica Acta - Protein Structure and Molecular Enzymology, vol. 1476, no. 1, pp. 75-84, 2000.

[23] C. O. Fagain, "Enzyme stabilization-recent experimental progress," Enzyme and Microbial Technology, vol. 33, pp. 137-149, 2003.

[24] J. K. Kaushik and R. Bhat, "Thermal stability of proteins in aqueous polyol solutions: role of the surface tension of water in the stabilizing effect of polyols," Journal of Physical Chemistry B, vol. 102, no. 36, pp. 7058-7066, 1998.

[25] Q. K. Beg and R. Gupta, "Purification and characterization of an oxidation-stable, thiol-dependent serine alkaline protease from Bacillus mojavensis," Enzyme and Microbial Technology, vol. 32, no. 2, pp. 294-304, 2003.

[26] B. Ghorbel, A. Sellami-Kamoun, and M. Nasri, "Stability studies of protease from Bacillus cereus BG1," Enzyme and Microbial Technology, vol. 32, no. 5, pp. 513-518, 2003. 

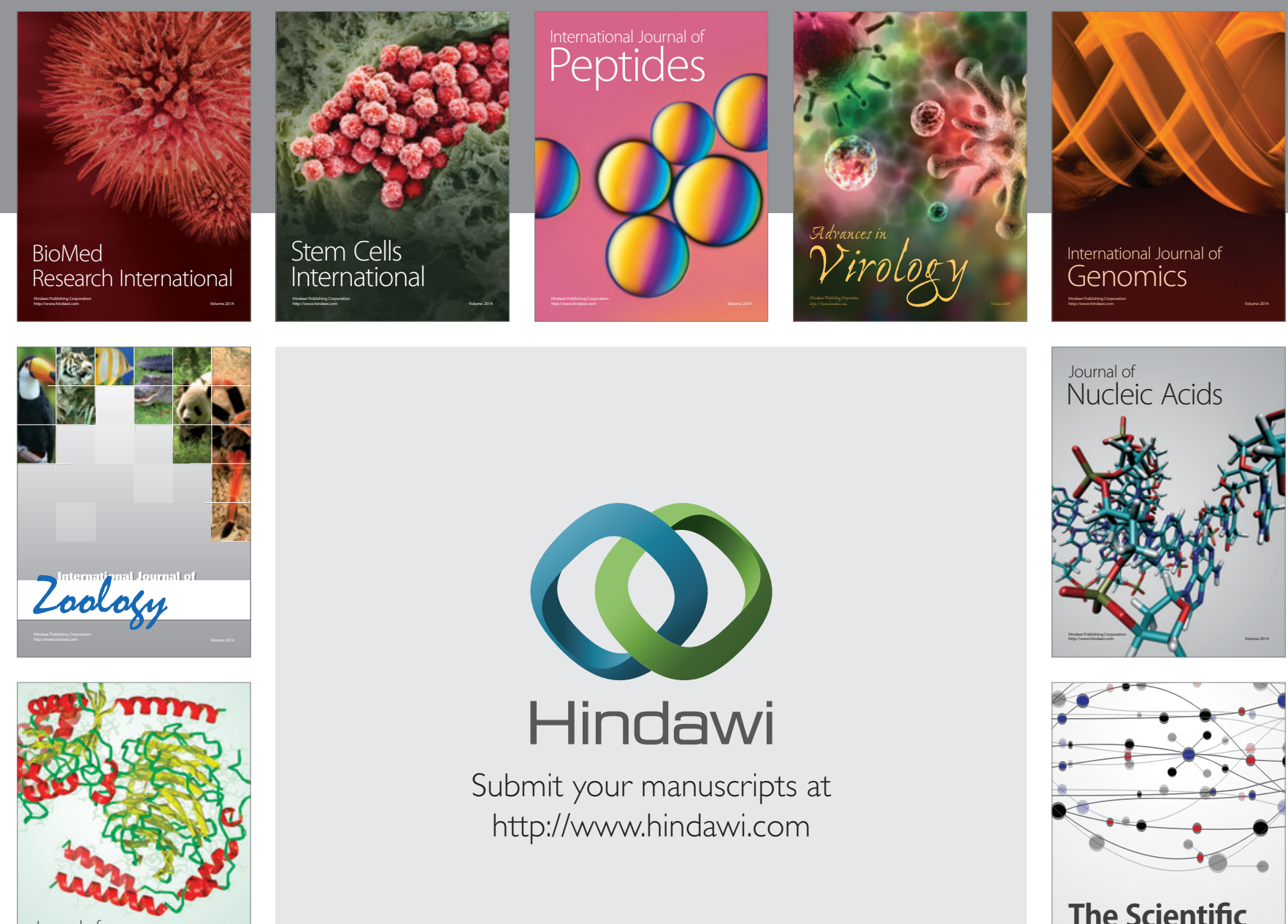

Submit your manuscripts at

http://www.hindawi.com

Journal of
Signal Transduction
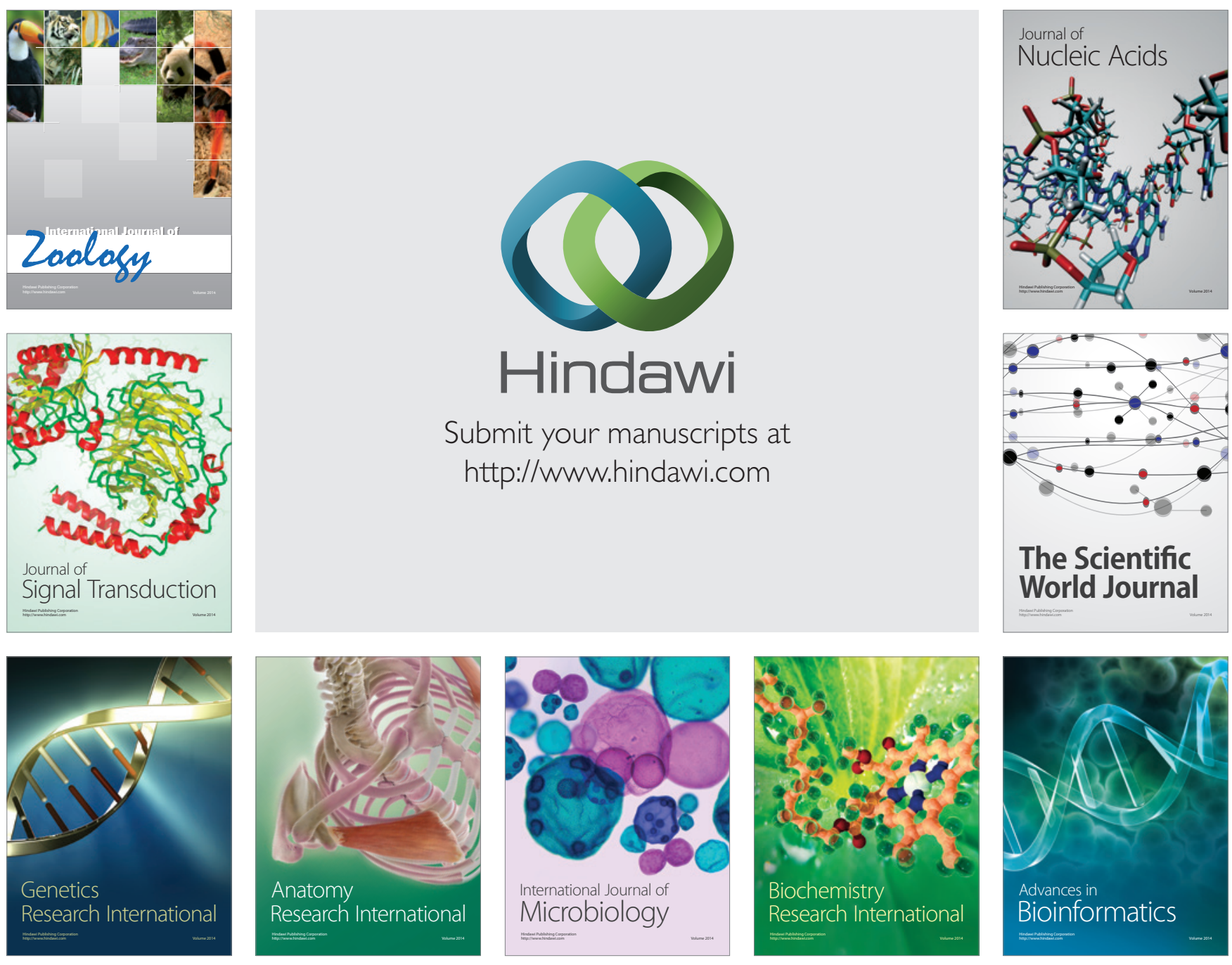

The Scientific World Journal
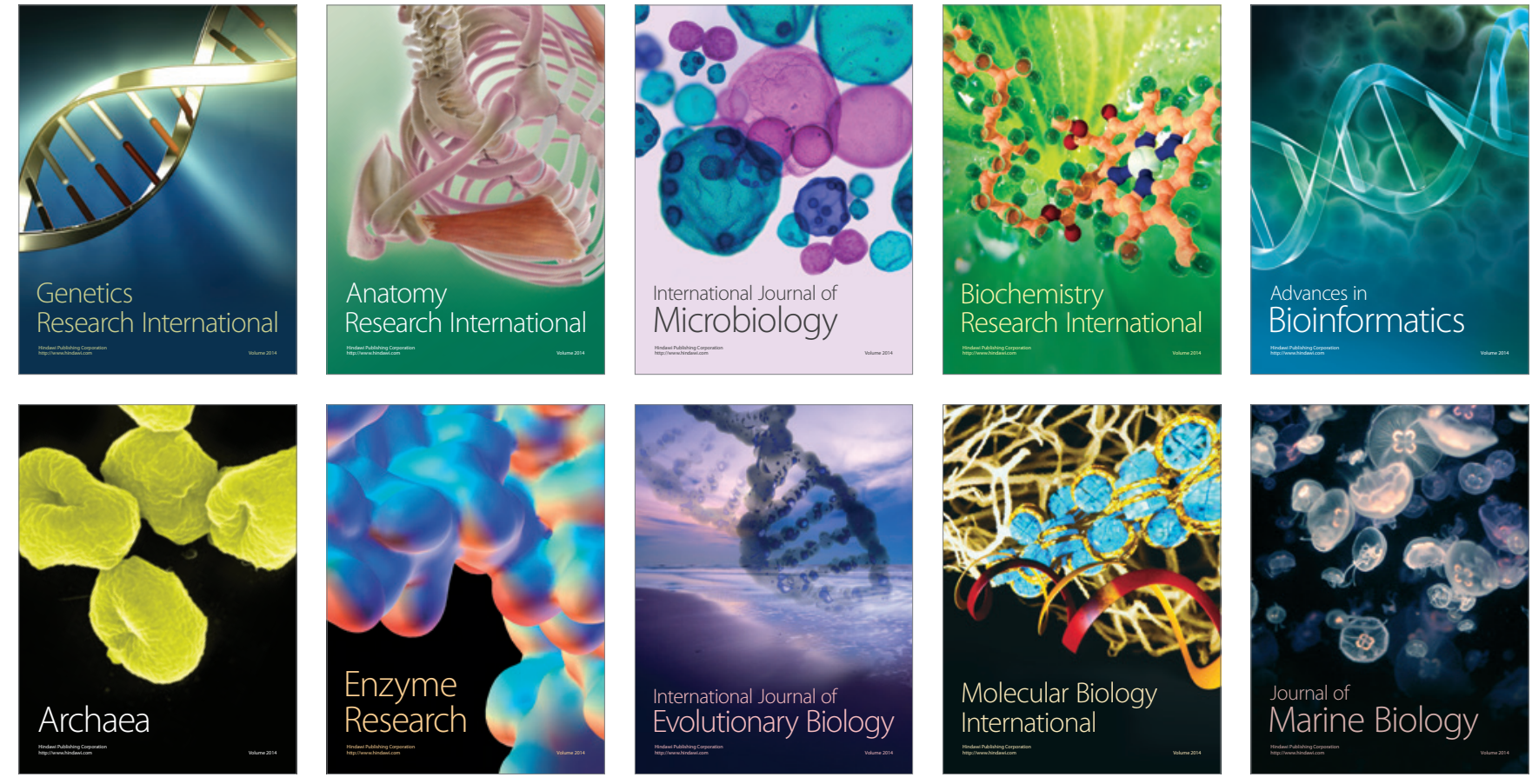